ence would need to be grounded in a much richer deep-historical discussion of the kind flagged in my opening paragraph above, then on the other hand its genealogies require far more elaborate analysis of the immediate contexts than this pared-down political narrative remotely allows. Moreover, nowhere is "left" ever defined, allowing Rizas to ignore both the dramatic popular-democratic upsurge of "1968" (i.e. not just the events per se, but all of the surrounding turbulence of 1967-75, including the largest pan-European strike wave since the 1920s) and the later emergence of Eurocommunism (which more than anything else drove the Cold War anxieties of NATO and the US). The more detailed omissions and consequent distortions of the account are far too numerous to mention. For example, the pivotal role of the SPD in both funding and politically shaping the otherwise flimsy implantations of Spanish and Portuguese socialism is entirely effaced by foregrounding the British Labour Party, whose prominence is an artifact of the book's restrictive "Anglo-American" focus. Vast historiographies go unmentioned. Astonishingly, for instance, neither the monographs of Richard Gillespie and Donald Share on the Spanish Socialist Party (each 1989), nor the older classic of Raymond Carr and Juan Pablo Fusi, Spain: Dictatorship to Democracy (1981), nor Pamela Radcliff's recent Making Democratic Citizens in Spain: Civil Society and the Popular Origins of the Transition, 1960-78 (2011) are captured in the bibliography.

Geoff Eley University of Michigan

\title{
Judith A. Layzer, Open for Business: Conservatives' Opposition to Enviro- nmental Regulation (Cambridge, MA: MIT Press, 2012).
}

The ideological conflicts that have characterized US politics over the past few decades are rarely as apparent as they are in environmental policy. In Open for Business, Judith Layzer carefully documents these policy debates over the last four decades of modern environmental politics. The result is a detailed and insightful narrative of the role of political conservatives in shaping environmental regulation. This conservative influence has been well coordinated, sustained over many decades, and effective in impeding progress, if not in rolling back basic environmental protections. The consequences for the nation and, given the need for US leadership, for the world are profound.

The book includes a chapter on policy theory as a framework for analyzing the influence of conservative ideas and politics. This is a useful review in its own right, but is not essential for following the story in the book. Except for the conclusion, the remaining chapters are organized chronologically, beginning with the "environmental decade" of the 1970s and following the story from the Reagan 
through to the second Bush administrations. The three issues of air quality, endangered species protection, and climate change provide the cases for in-depth analysis against the larger backdrop of conservative ideas and influences. The writing is lively, the research is thoroughly documented, and the political analysis is astute.

The ideological touchstones of the conservative arguments are limited government, unrestrained growth, property rights, and free markets. Interestingly, there is little interest in conservation in this conservative critique. This was not always the case. There was a time when moderate Republicanism made substantial contributions to environmental protection. Such leaders as Russell Train, William Ruckelshaus, and William Reilly were pragmatic regulators who led with integrity and pushed their party and presidents to deal responsibly with the environment. Yet that tradition, like much of the middle in American politics, is gone, at least for the moment. The result is that environmental politics has become increasingly polarized, and progress of any kind is more difficult. That story comes through clearly in this book.

The book does have its own limitations from a policy perspective. Environmental agencies do important and necessary work, and much of it is done well. The practical reality is, however, that many environmental regulations are cumbersome and difficult to implement, cost more than they should, and present firms with a complex and often contradictory array of requirements from multiple levels of government. A recurring theme in the book is that efforts to improve or reform regulation are motivated solely by politics. Yet serious advocates of environmental protection who see a need to improve the regulatory system in response to new problems and relationships have led much of this effort at reform. Like much of the environmental policy literature, there is an assumption that what emerges from the high level regulatory struggle is what matters most and implementation on the ground an afterthought. It is also worth acknowledging that the left has its own storylines, techniques, and public relations tools; none of this is the exclusive domain of the right. The right may be more unscrupulous, and their ends far less defensible, but both sides know how to play the game.

What is most disturbing about the story that Layzer so ably tells, especially over the last decade or so, is the cynicism and lack of integrity with which the attacks from the far right have been argued. The trashing of mainstream environmental (especially climate) science and a willingness to interfere with scientific and policy analysis before they can be debated in the political sphere is a disturbing trend. The consequences for energy and climate, public health, habitat protection, and many other critical issues are obvious, and at some point the economic as well as ecological costs will become overwhelming. Even more consequential, however, is that the nation that once was and should still be a leader in addressing the environmental, energy, and resource challenges of our time is hobbled by the opposition and opportunism of the right. Without leadership from the US, the limits of global ecosystems will increasingly be at risk, and their limits eventually 
will be breached. The ultimate cost of conservative influence may be the lost opportunity and the damages not only to the environment, but also to the physical and social foundations on which further progress in human well-being depends.

Judith Layzer has done a remarkable service with this thoughtful, wellresearched, and compelling analysis of the conservative influence on environmental regulation. That she could have given a bit more of the other side of the story is a minor complaint in the face of the important contributions she makes in this book. Anyone interested in American politics, and not just environmental politics, will benefit from this impressive political and historical analysis.

\section{Daniel Fiorino \\ American University}

\section{Eric Muller, Colors of Confinement: Rare Kodachrome Photographs of Japanese American Incarceration in World War II (Chapel Hill: University of North Carolina Press, 2012).}

Eric Muller's remarkable new book, Colors of Confinement, acquaints readers with the marred history of the Japanese American incarceration experience during World War II through Bill Manbo's family stories and photos. Not only do these stunning colour images provide a unique view into the lives of Americans incarcerated during World War II, but they also reveal the deeper issues of civil liberties violations and racism on the home front through the lens of Manbo. The Japanese American incarceration was one of the worst civil liberties violations the United States government engaged in; violating Americans' civil liberties, the constitution, and allowing for the presence of institutionalized racism in military and presidential executive orders due to fear and war hysteria dictating national policy. Heart Mountain was one of ten American incarceration camps during World War II where people of Japanese ancestry were sent if they lived on the West Coast.

Muller clearly states he does not focus on what the images show, but rather on what they concealed (1). His essay provides great context in which the story of Bill Manbo and his family takes place. He describes the aggressive policies the United States enacted to limit Japanese immigration and naturalization while telling of the incarceration experience Manbo and his family endured, which was very similar to other families who were forcibly removed from their homes. Muller details the uprooting of the Manbo family to the Santa Anita Assembly Center where they were housed in horse stables that reeked of the former occupants (6). He retraces the story of the Manbo family's transfer to Heart Mountain and their "interrupted lives" there (1). Muller touches on the divisive 